\title{
PENERAPAN METODE DRILL UNTUK MENINGKATKAN HASIL BELAJAR PASSING BAWAH BOLA VOLI SISWA KELAS VII.A SMP NEGERI 2 BATUKLIANG TAHUN PELAJARAN 2016/2017
}

\author{
MUH. EDI ALWIJAYA \\ SMP Negeri 2 Batukliang
}

\begin{abstract}
ABSTRAK. Tujuan penelitian ini adalah untuk mengetahui peningkatan hasil belajar passing bawah pada permainan bola voli melalui penerapan metode drill pada siswa kelas VII.A SMP Negeri 2 Batukliang terdiri dari 23 siswa. Instrumen yang digunakan untuk mengukur keberhasilan aktivitas guru dan siswa dalam kegiatan belajar mengajar yakni dengan menggunakan lembar observasi, sedangkan untuk mengukur hasil belajar siswa adalah dengan tes kognitif, afektif dan psikomotor. Penelitian ini dilaksanakan dalam dua siklus. Tahapan dalam penelitian ini mengikuti prosedur penelitian tindakan kelas, yaitu: (1) perencanaan, (2) pelaksanaan tindakan, (3) pengamatan, dan (4) refleksi. Data penelitian dianalisis dengan menggunakan teknik persentasi dimana pada siklus I tingkat ketuntasan aktifitas guru dalam melaksanakan kegiatan pembelajaran baru mencapai 72,72\% dan meningkat pada siklus II menjadi $100 \%$. untuk data ketuntasan belajar siswa $70 \%$ dan mengalami peningkatan pada siklus II menjadi 90\%, hal ini telah melebihi standar yang didasarkan kriteria ketuntasan minimal yakni 85\%. Sedangkan hasil belajar siswa pada siklus I baru mencapai $65,22 \%$ meningkat pada siklus II menjadi $91,30 \%$ atau telah mencapai tingkat ketuntasan belajar yang ditetapkan oleh sekolah yakni 75\%. Dengan demikian dapat disimpulkan bahwa penerapan metode drill dapat meningkatkan hasil belajar passing bawah bola voli siswa kelas VII.A SMP Negeri 2 Batukliang Kabupaten Lombok Tengah.
\end{abstract}

Kata Kunci: Penerapan Metode Drill, Hasil Belajar Passing Bawah, Permainan Bola Voli

Abstract; The purpose of this study was to determine the increased of under passing learning outcomes in volleyball games troungh the application of drill methods in class VII.A of SMP Negeri 2 Batukliang south buton regency. Subjects in this is a class VII.A of SMP Negeri 2 Batukliang consist of 23 students. The insrtument used to measure the success of teaching teacher and student in teaching and learning activities by using cognitive, affective and psycomotor test. This studi was conducted in two cycles. The stages in this study followed the action research procedure, namely: (1) planning, (2) action, (3) observation and (4) reflection. Data were analyzed using the persentation techniques in which at the first cycle of completeness level of teachers activities in implementing the learning activities reached $72.72 \%$ and increased in to the second cycle to be 100 , completeness data of students learning to $70 \%$ and increased in to the second cycle to $90 \%$. in this case that is has been more of sandar based on minimum completeness criteria namely $85 \%$. While the students learning outcomes in the first cycle just reached $65,22 \%$, increased in the second cycle to be $91.30 \%$ or has been completeness level of learning which assigned by the school that is $75 \%$. It can be concluded that the application of drill method could be increase of under of passing learning outcomes in volleyball games in class VII.A of SMP Negeri 2 Batukliang Lombok center Regency.

Keyword: Application Of Drill Method, Under Passing Learning Outcomes, Olleyball Games

\section{PENDAHULUAN}

Tujuan Pendidikan Nasional menurut UU No. 20 tahun 2003 pasal 3 adalah mengembangkan potensi peserta didik supaya menjadi manusia yang beriman, bertaqwa kepada Tuhan Yang Maha Esa, berahklak mulia, sehat, berilmu, cakap, kreatif, mandiri dan menjadi warga negara yang demokrasi serta bertanggung jawab. Ini merupakan tanggung Jawab bersama khususnya guru untuk turut mencerdaskan bangsa, diantaranya melalui pendidikan formal mulai dari sekolah 
dasar sampai perguruan tinggi. kegiatan belajar merupakan kegiatan yang amat komplek bukan saja menyangkut aspek kejiwaan tetapi juga aspek fisik, maka guru harus berupaya semaksimal mungkin dalam menata lingkungan belajar dan perencanaan materi pembelajaran yang matang agar terjadi proses pembelajaran yang efektif baik itu didalam maupun diluar kelas guru harus mengenal substansi yang dipelajari menyangkut aspek kognitif, afektif dan psikomotor.

Pendidikan jasmani adalah proses pendidikan yang menyeluruh yang menggunakan aktivitas fisik dengan permainan dan olahraga sebagai alatnya, Rusli Lutan, (2001). Dengan demikian dapat diduga dengan muda bahwa tujuannya bukan sekedar pencapaian yang bersifat fisik semata, akan tetapi juga melibatkan aktivitas psikis.

Program pengajaran pendidikan jasmani memiliki 6 jenis ruang lingkup yaitu: (1) aktivitas permainan dan olahraga, (2) aktivitas pengembangan, (3) aktivitas uji diri, (4) aktivitas ritmik, (5) aktifitas air, dan (6) aktifitas luar sekolah/alam bebas. Seluruh jenis aktivitas tersebut diharapkan dapat dilaksanakan oleh sekolah, namun jika di sekolah atau disekitar tidak terdapat sarana dan prasarana penunjang, maka aktivitas tersebut dapat diganti dengan aktifitas fisik lain yang memungkinkan dapat dilaksanakan disekolah. Pendidikan jasmani di sekolah mempunyai tujuan selain untuk meningkatkan kesegaran jasmani juga untuk membentuk nilai kognitif (pengetahuan), afektif (sikap) dan psikomotor (gerak) peserta didik. Dalam pendidikan jasmani terdiri atas beberapa permainan atau olahraga, salah satunya adalah permainan bola voli.

Bola voli merupakan suatu permainan beregu yang dimainkan oleh dua tim yang saling berhadapan dan masing-masing terdiri dari enam pemain. Permainan bola voli sangat terkenal dimasyarakat, dimulai dari kalangan atas sampai kalangan bawah sudah tidak asing lagi dengan nama permainan bola voli. Sering dijumpai didaerah-daerah tertentu permainan bola voli ini dimainkan oleh banyak orang mulai dari anak-anak sampai dewasa.
Kebanyakan orang memainkan bola voli ini untuk mengisi waktu luang, mencari keringat, dan bahkan untuk meningkatkan prestasi.

Permainan bola voli terdiri atas beberapa teknik, diantaranya teknik dengan menggunakan bola yang meliputi servis, passing bawah, passing atas, umpan, smash, dan block (Suharno,1984). Pasing merupakan salah satu teknik dalam permainan bola voli, yang jika ditinjau dari segi taktik sudah merupakan suatu serangan awal untuk memperoleh nilai agar suatu regu berhasil meraih kemenangan (M. Yunus,1992). Passing harus dilakukan dengan baik dan sempurna oleh semua pemain karena kesalahan pemain mengakibatkan pertambahan angka dari lawan.Demikian pentingnya kedudukan passing dalam permainan bola voli maka passing harus dilakukan dengan baik, oleh karena itu passing harus terarah dan terukur dengan tujuan agar kawan yang berposisi sebagai spiker mudah melakukan spike yang akurat.

Teknik melakukan passing bermacammacam menurut Suharno (1979), ada dua macam pukulan passing yang dikenal dan sering dimainkan yaitu passing atas dan passing bawah. Passing bawah adalah passing yang sering digunakan oleh pemain pemula karena jenis passing ini merupakan passing yang sangat sederhana dan mudah. Gerakan passing bawah lebih alamiah dan tenaga yang dibutuhkan tidak terlalu besar (M. Yunus,1992). Passing bawah ini sesuai diajarkan terutama untuk pemain yang masih dalam taraf berlatih/belajar seperti anak sekolah. Hal tersebut sesuai dengan pernyataan Herry Koesyanto (2003), bahwa bagi pemain pemula cara akan lebih mudah untuk mempelajari passing bawah karena tenaga yang dibutuhkan tidak terlalu besar sehingga dalam waktu yang singkat sudah dapat menguasai.

Pembelajaran bola voli siswa dapat belajar bergerak dan belajar melalui gerak (Rusli Lutan, 2001). Belajar bergerak menekankan pada kemampuan siswa untuk dapat melakukan gerakan-gerakan dalam permainan bola voli. Nilai-nilai luhur yang terkandung yaitu kerja sama, toleransi, kejujuran, saling menghargai, menghormati, 
disiplin dan sebagainya. Dalam hal ini diperlukan metode mengajar yang tepat, karena dengan penerapan metode yang tepat bagi anak didik memberikan hasil pengajaran yang diperoleh dapat membuahkan hasil berupa keterampilan bermain yang optimal terutama untuk pembelajaran bola voli di sekolah.

Berdasarkan kenyataan dilapangan bahwa kemampuan passing bawah tingkat SMP khusunya siswa kelas VII.A SMP Negeri 2 Batukliang Kabupaten Lombok Tengah tahun pelajaran 2016/2017 semester Ganjil masih rendah yakni $60 \%$ dari 22 siswa hanya 13 orang yang mencapai nilai kriteria ketuntasan minimal (KKM) dari sekolah. Hal ini dibuktikan dengan banyak diantara peserta didik yang belum mampu melakukan passing bawah secara sempurna. Salah satu penyebab utama kegagalan dari proses pembelajaran adalah penerapan metode pembelajaran yang konvesional yakni lebih menekankan pada dominasi peran guru. Hal ini berdampak pada ketidak seriusan dan rasa bosan mengikuti proses pembelajaran. Berdasarkan pada kondisi tersebut, maka peneliti mencoba untuk menerapkan pembelajaran dengan menggunakan metode metode drill.

Keunggulan menggunakan metode drill adalah peserta didik memperoleh ketangkasan dan kemahiran dalam melakukan suatu gerakan sesuai dengan apa yang dipelajarinya, akan menimbulkan rasa percaya diri peserta didik yang berhasil dalam belajar, karena telah memiliki keterampilan khusus yang akan berguna dikemudian hari. Dan guru akan lebih muda mengontrol dan membedakan mana peserta didik yang disiplin, dengan memperhatikan tindakan dan perbuatan peserta didik saat berlangsungnya proses belajar mengajar, (Harja Sapoetra, harjasapoetra.blogspot.co.id).

Berdasarkan uraian diatas, maka peneliti termotivasi untuk melakukan sebuah penelitian dengan judul penerapan metode drill untuk meningkatkan hasil belajar passing bawah bola voli Siswa kelas VII.A SMP Negeri 2 Batukliang Kabupaten Lombok Tengah.

\section{Rumusan Masalah}

Berdasarkan uraian latar belakang diatas, maka masalah penelitian ini dirumuskan sebagai berikut : apakah dengan menerapkan metode drill dapat meningkatkan hasil belajar passing bawah bola voli siswa kelas VII.A SMP Negeri 2 Batukliang?

\section{Tujuan Penelitian}

Tujuan penelitian ini adalah untuk mengetahui apakah dengan menerapkan metode drill dapat meningkatkan hasil belajar passing bawah bola voli siswa kelas VII.A SMP Negeri 2 Batukliang.

\section{Manfaat Penelitian}

Manfaat dari penelitian ini adalah sebagai berikut:

1. Manfaat bagi Guru:

Sebagai tambahan referensi bentuk pembelajaran yang dapat digunakan guru pendidikan jasmani olahraga dan kesehatan dalam meningkatkan hasil belajar siswa khususnya materi passing bawah pembelajaran bola voli.

2. Manfaat bagi siswa:

Meningkatkan hasil belajar siswa khususnya pokok bahasan passing bawah pada pembelajaran bola voli.

3. Manfaat bagi peneliti:

Menjadi pengalaman berharga dalam melakukan suatu penelitian tindakan kelas menggunakan metode drill.

\section{TINJAUAN PUSTAKA}

\section{Hakekat Hasil Belajar}

Berbicara mengenai hasil belajar tentu tidak terlepas dari proses belajar dimana seseorang yang telah mengalami proses belajar akan memperoleh hasil belajar. Didalam kamus bahasa indonesia prestasi diartikan hasil yang telah dicapai. Selanjutnya Arifin (1991), menyatakan bahwa prestasi berarti hasil usaha dalam hubungannya dengan usaha belajar berarti menunjukan tingkat keberhasilan yang dicapai oleh siswa setelah melakukan kegiatan tertentu. Prestasi belajar adalah hasil belajar dari suatu individu tersebut berinteraksi secara aktif dan pasif dengan lingkungannya.

Melakukan kegiatan belajar akan terjadi proses berpikir yang melibatkan kegiatan mental, terjadi penyusunan hubungan 
informasi-informasi yang diterima sehingga timbul suatu pemahaman dan pengetahuan terhadap materi yang diberikan. Dengan adanya pemahaman dan penguasaan yang didapat setelah melalui proses belajar mengajar maka siswa telah memahami suatu perubahan yang tidak diketahui menjadi diketahui. Perubahan inilah yang disebut dengan hasil belajar.

Hasil belajar merupakan perolehan kebiasaan-kebiasaan, pengetahuan dan sikap. Perolehan ini termasuk suatu cara baru melakukan sesuatu dan cara mengatasi masalah pada situasi baru (Ahmad Sofyan, 2006). Hasil belajar merupakan respon (tingkah laku) yang baru, pada dasarnya respon yang baru itu sama pengertiannya dengan tingkah laku (pengetahuan, sikap, katerampilan) yang baru (Nurdin Ibrahim, 2005).

Berkaitan dengan hasil belajar yang di peroleh, terdapat tipe hasil belajar menurut Sudjana (2004), yaitu :

1. Tipe hasil belajar kognitif meliputi pengetahuan, pemahaman, penerapan, analisis sintesis, dan evaluasi.

2. Tipe hasil belajar bidang afektif meliputi penerimaan, jawaban, penilaian, organisir, dan karakteristik nilai.

3. Tipe hasil belajar bidang psikomotor meliputi tingkatan keterampilan .

Berdasarkan Pernyataan diatas dapat disimpulkan bahwa hasil belajar merupakan adanya suatu perubahan yang berupa perubahan tingkah laku (psikomor), pengetahuan (kognitif), dan sikap (afektif) yang diperoleh seseorang setelah melakukan proses kegiatan belajar.

Pencapaian belajar atau hasil belajar diperoleh setelah dilaksanakannya suatu program pengajaran. Penilaian atau evaluasi pencapaian hasil belajar merupakan langkah untuk mengetahui seberapa jauh tujuan kegiatan belajar mengajar (KBM) suatu bidang studi atau mata pelajaran telah dapat dicapai (Bambang Subali dan Paidi, 2002).

Hasil belajar yang dilihat dari tes hasil belajar berupa keterampilan pengetahuan intelegensi, kemampuan dan bakat individu yang diperoleh di sekolah biasanya dicerminkan dalam bentuk nilai-nilai tertentu.
Tes bertujuan untuk membangkitkan motivasi siswa agar dapat mengorganisasikan pelajaran dengan baik.

Teknik Dasar Passing Bawah Permainan Bola Voli

Teknik dasar adalah cara melakukan sesuatu untuk mencapai tujuan tertentu secara efektif sesuai dengan peraturan yang berlaku untuk mencapai hasil yang optimal, Horsono (1988). Jadi untuk mengembangkan dan memenangkan sesuatu diperlukan teknik dan taktik yang benar. Teknik dasar permainan bola voli selalu berkembang sesuai dengan perkembangan pengetehuan dan teknologi dan ilmu-ilmu lain. Adapun teknik-teknik dalam permainan dalam bola voli meliputi :
a. Service
b. Passing
c. Umpan
d. Smash
e. Bendungan (m. Yunus, 1992).

Dalam penelitian ini yang menjadi fokus permasalahan adalah teknik dasar passing, sehingga yang menjadi penekanan pada kajiannya adalah pada teknik passing saja.

Menurut Bonnie Robbinson (1989) bahwa passing merupakan teknik dasar yang paling penting dalam permainan bola voli. Passing juga adalah operan bola kepada teman seregunyauntuk dimainkan dalam lapangan sendiri. Dengan menguasai passing berarti permainan bisa berlangsung dengan baik, sebab passing merupakan salah satu teknik untuk menerima bola yang dilontarkan oleh lawan. Dalam menerima bola, sebagai penerima harus mengambil sudut yang tepat, memutuskan kemana harus mengumpankan bola dan selanjutnya mengontrol umpan sesuai dengan kedipan mata. Oleh sebab itu dalam belajar keterampilan, yang pertama kali dikuasai oleh pemain adalah teknik dalam passing.

Passing dan umpan dapat dilakukan dengan dua cara yaitu dari bawah dan dari atas. Passing bawah digunanakan apabila bola yang datang dibawah ketinggian dada, Amung Ma'mum \& Toto Subroto (2001). Cara melakukan teknik passing bawah dan passing atas sangat berbeda. Pada umumnya passing bawah tidak melibatkan jari-jari, akan tetapi 
bola menyentuh bagian dan pergelangan tangan, biasanya dilakukan dengan satu atau dua tangan. Sedangkan passing dan umpan dari atas pada umumnya melibatkan jari-jari tangan.

Mengoper atau passingbola digunakan untuk menerima servis, menerima smash dan mengambil bolayang datangnya rendah serta bola yang memantul dari net. Operan lengang bawah sering digunakan untuk mengarahkan bola kepada teman satu tim. Operan lengan juga merupakan awalan dari sebuah penyerangan. Dari beberapa pernyataan diatas dapat disimpulkan bahwa passing bawah merupakan salah satu teknik dasar dalam permainan bola voli dengan menggunakan rangkaian gerak peran kedua lengan bawah yang berfungsi baik untuk menahan maupun untuk mengumpan bola.

Menurut Nuril Ahmadi (2007) bahwa passing atau peran lengan bawah merupakan satu rangkayan melakukan operan dengan lengang bawah yang terdiri dari: (1) sikap awal; (2) pelaksanaan; (3) gerak lanjutan.

Sikap awal, kedua kaki dibuka selebar bahu, salah satu kaki berada di depan, lutut ditekuk dengan togok dibungkukkan. Pandangan mengikuti gerakan pemain lawan dan gerak datangnya bola. Kedua tangan berada diantara bahu dan lutut, tubuh rileks. Berat badan pada telapak kaki bagian depan. Posisi tangan yang menyerupai mangkok direkomendasikan karena pada umumnya posisi ini merupakan bentuk yang paling menguntungkan dan memungkinkan pemain untuk membentuk bidang yang sejajar dengan permukaan lengan bawah yang rata. Cara ini membantu memastikan bola melambung ke sasaran dengan normal. Pada saat kontak dengan bola, pinggang tetap sedikit dibungkukkan dan lutut dilenturkan, memindahkan berat badan menjadi agak maju ke arah bola atau melangkah sedikit ke arah sasaran dengan kaki yang berada di depan untuk mulai.

Pelaksanaan, bergerak ke arah bola dan mengatur posisi tubuh, kedua jari tangan saling menggenggam. Siku diputar sehingga bagian lengan yang datar menghadap ke atas. Tangan sejajar dengan paha. Bola di arahkan dengan tubuh, melalui gerakan mengulurkan kaki sambil mengayunkan lengan. Perkenaan pukulan bola harus jauh dari tubuh, pandangan selalu kearah bola.

Gerakan lanjutan, setelah bola dipukul kedua jari tetap tergenggam. Siku tatap terkunci, lengan sejajar berada dibawah bahu. Lebih jelasnya cara melakukan passing bawah dalam permainn bola voli dapat dilihat pada gambar 2.1. dibawah ini.

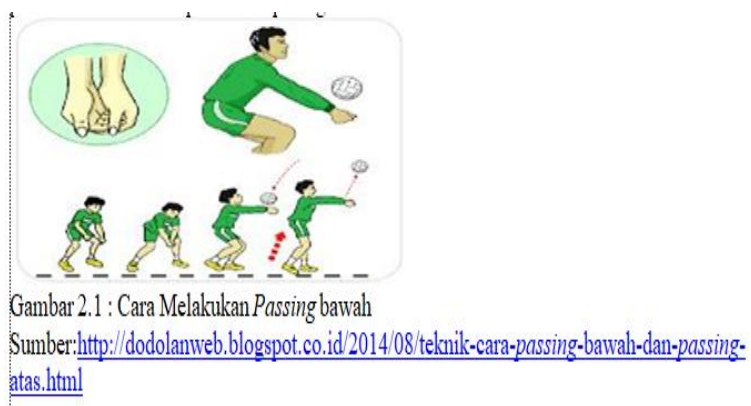

\section{Permainan Bola Voli}

\section{Sejarah Permainan Bola Voli}

Permainan bola voli diciptakan oleh William G. Morgan pada tanggal 9 Februari 1895, di Holyoke, Massachusetts (Amerika Serikat) dia seorang Guru pendidikan jasmani di Young Man's Cristian Association (YMCA). Beliau dilahirkan di Lockport, New York pada tahun 1870, dan meninggal pada tahun 1942.

Permainan ini semula disebut "Minonette" yaitu permainan memantul-mantulkan bola menyebrangi atas net dan bola tidak boleh menyentuh lantai . bola yang digunakan terbuat dari bola bagian dalam bola basket, net yang digunakan adalah net tenis yang digantungkan setinggi 2,16 meter dari permukaan lantai. Jumlah pemain di sini tak terbatas, karena sesuai dengan tujuan semula yakni untuk mengembangkan kesegaran jasmani para buruh. William G. Morgan kemudian melanjutkan idenya untuk mengembangkan permainan tersebut agar mencapai cabang olahraga yang dipertandingkan. Dan pada tahun 1896 permainan kemudian menjadi volleyball yang artinya memvoli bola. Demonstrasi pertandingan pertamanya di International YMCA Training School.

Permainan bola voli menyebardan populer ke daratan Eropa diantaranya Belanda sekitar tahun 1925 yang dipopolerkan oleh mahasiswa 
dikota Uden oleh S. Buis dan tahun 1947 didirikanlah Netherlan Volleyball Bond (NEVOBO). Bola voli juga berkembang dinegara-negara Eropa lainya seperti Belgia, Bulgaria, Hongaria, Inggris, Italia dan negaranegara Eropa lainya. Setelah masing masing negara mendirikan induk organisasi maka timbulah pemikiran untuk mendirikan induk organisasi internasional dan pada tahun 18 April 1947 di dirikanlah International Volleyball Federation (IVBF) yang beranggota 15 negara dan berkantor di Paris yang diketuai oleh Paul Libaud.

Perkembangan bola voli di Asia, mulai dari India tahun 1900 oleh De Gray, seorang ahli pendidikan jasmani dari YMCA. Di daratan Cina diperkenalkan oleh Gayli dan Robetson juga dari YMCA. Sedangkan Jepang, Korea dan Filipina mulai diperkenalkan antara 19101913 oleh Elwood E Brown. Negara Asia yang pertama masuk IVBF adalah Libanon tahun 1947. Pada tahun1951 Filipina dan Jepang resmi menjadi anggota IVBF. Kedua negara inilah yang mempelopori negara-negara Asia lainya menjadi anggota IVBV. Kemudian dalam rangka memperingati 1 tahun berdirinya Asian Volleyball Federation tahun 1955, Jepang menyelenggarakan kejuaraan bola voli Asia 1 dan india keluar sebagai juaranya.

Indonesia mengenal permainan bola voli sejak tahun 1928 pada zaman penjajahan Belanda. Diperkenalkan oleh guru-guru Belanda yang bertugas disekolah-sekolah lanjutan HBS dan AMS dan tentara Belanda. Selain itu angkatan laut Jepang (saat pendudukan tentara Jepang) ikut pula memperkenalkan permainan bola voli terutama di Indonesia bagian Timur. Setelah indonesia merdeka, banyak bekas tentara Belanda yang bergabung dengan TNI dan ikut serta mempopulerkan permainan bola voli pada masyarakat Indonesia. Permainan bola voli di Indonesia sangat pesat di seluruh lapisan mayarakat, sehingga timbul klub-klub di kota besar di seluruh Indonesia. Pembentukan induk organisasi bola voli dipelopori oleh Ikatan Perkumpulan Volleyball Surabaya (IPVOS) dan Persatuan Volleyball Indonesia Djakarta (PERVID). Atas jasa baik dari ketua komisi teknik Komite Olimpiade Indonesia (KOI), Dr Azis Saleh, diadakanlah rapat pembentukan Induk Organisasi Bola Voli Indonesia oleh IPVOS dan PERVID, di salah satu lapangan Ikada (sekarang lapangan Monas) yang juga dihadiri oleh tokoh-tokoh olahraga lainya. Dalam rapat tersebut disepakati sebagai berikut :

1. IPVOS dan PERVID bersepakat mempelopori pembentukan top Organisasi Bola Voli Indonesia

2. Menunjuk Bapak Wim. J Latumeten sebagai formatur untuk menyusun pengurus top Organisasi Bola Voli Nasional Indonesia.

Dengan dasar itulah maka pada tanggal 22 Januari 1955 terbentuklah Persatuan Bola Voli Seluruh Indonesia (PBVSI) yang diketuai oleh Wim J. Latumeten. Pada maret 1955 PBVSI disahkan oleh KOI menjadi satu-satunya Induk Organisasi Bola Voli yang resmi di Indonesia. Pada tahun yang sama PBVSI menerima pengesahan sementara menjadi anggota FIVB. Pada tahun 28 sampai 30 Mei pengurus pusat PBVSI menyelenggarakan kejuaraan Nasional pertama untuk seluruh Indonesia. Dari sejak itu PBVSI aktif mengembangkan kegiatankegiatan baik ke dalam maupun ke luar negeri sampai sekarang.

Perkembangan permainan bola voli sangat menonjol saat menjelang Asian Games IV 1962 dan Ganefo I 1963 di Jakarta.Pekan Olahraga Nasional PON II 1951 di Jakarta, permainan ini resmi dipertandingkan dan menjadi salah satu cabang olahraga yang dipertandingkan dalam setiap PON. Pada bulan Oktober 1959 sesuai dengan keputusan IVBF Meeting Budapest, (PBVSI) resmi menjadi anggota IVBF ke-62.

\section{Pengertian Permainan Bola Voli}

Permainan bola voli adalah memainkan bola dengan net dan menjatuhkan bola di dalam lapangan permainan lawan dengan menyeberangkan bola melewati jaring dan mempertahankan bola agar tidak jatuh di bidang permainan sendiri (Sukintaka 1983).

Permainan bola voli menurut Suharno (1984) adalah olahraga yang dapat dimainkan oleh anak-anak sampai orang dewasa, baik pria maupun wanita. Dengan bermain bola voli akan 
berkembang secara baik unsur-unsur daya pikir, kemauan dan perasaan. Disamping itu kepribadian juga dapat berkembang dengan baik terutama disiplin, rasa kerja sama dan tanggung jawab terhadap apa yang diperbuatnya.

Manfaat lain dari bermain bola voli adalah: 1) kerja sama, 2) kecepatan bergerak, dan 3) lompatan yang tinggi untuk mengatasi bola yang berada diatas net (Suharno, 1984). Oleh karena itu permainan memerlukan fisik yang baik, postur tubuh yang tinggi dan atletis, sehat, terampil, cerdas dan sikap sosial yang tinggi agar dapat menjadi pemain yang berbobot baik dan dapat dikatakan sebagai pemain yang handal profesional.

Permainan bola voli merupakan suatu permainan yang kompleks karena membutuhkan teknik-teknik yang ada dalam bola voli diantaranya servis, passing dan smash, (Nuril Ahmadi, 2007). Sedangkan menurut Muhajir (2004), menyatakan bahwa tujuan permainan bola voli adalah memperagakan teknik dan taktik memainkan bola di lapangan untuk meraih kemenangan dalam setiap pertandingan. Beberapa pendapat diatas, dapat disimpulkan bahwa

permainan bola voli merupakan permainan beregu dimana masing-masing regu terdiri dari 6 pemain yang saling berhadapan dan memainkan bola maksimal tiga kali sentuhan kemudian bola diseberangkan melewati atas net dengan menggunakan teknik dan taktik untuk meraih kemenangan.

Dalam permainan bola voli teknik yang muncul adalah servis, passing, smash dan bloking.Tidak akan mudah memainkan bola voli tanpa ada kerjasama tim karena di dalam permainan bola voli dituntut untuk bekerjasama antara pemain satu dengan yang lain untuk menjatuhkan bola ke daerah lapangan permainan lawan dan mempertahankan agar bola tidak jatuh dibidang permainan sendiri.

Permainan bola voli memiliki aturan-aturan yang harus diketahui yaitu:

a. Sistem hitungan yang digunakan adalah 25 rally point. Bila poin peserta seri (2424) maka pertandingan akan ditambah 2 poin. Peserta yg pertama kali unggul dengan selisih 2 poin akan memenangi pertandingan.

b. Pada saat servis bola yang melewati lapangan dihitung sebagai poin bagi lawan, begitu juga sebaliknya penerima servis lawan yang membuat bola keluar dihitung sebagai poin bagi lawan.

c. Seluruh pemain harus berada di dalam lapangan pada saat servis dilakukan.

d. Bola servis menyentuh net tetapi masuk ke daerah lawan dianggap sah.

e. Kesalahan meliputi :

i. Pemain menyentuh net atau melewati garis batas tengah lapangan lawan.

ii. Tidak boleh melempar ataupun menangkap bola. Bola volley harus di pantulkan tanpa mengenai dasar lapangan.

3. Gambar dan Ukuran Lapangan Permainan Bola Voli

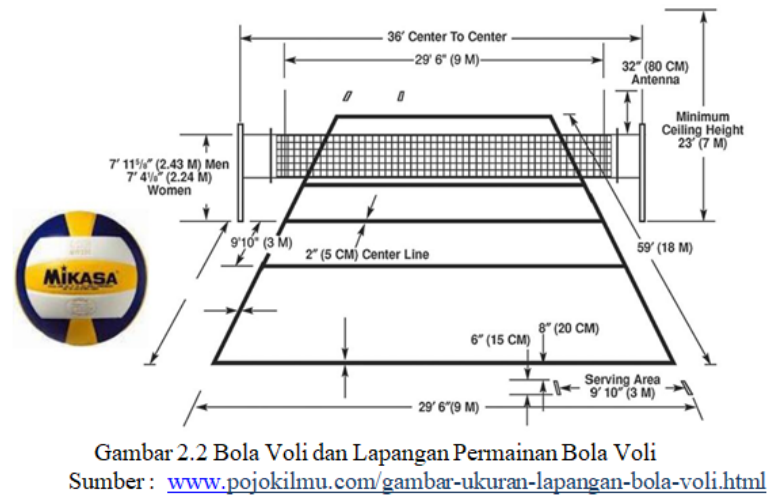

1. Ukuran lapangan $18 \times 9$ meter.

2. Jarak garis serang dengan garis tengah 3 meter.

3. Tinggi net putra 2,43 meter dan tinggi net putri 2,24 meter.

4. Lebar net $1 \mathrm{~m}$ dan panjang 9,50 - $10 \mathrm{~m}$ (dengan pita samping $25-50 \mathrm{~cm}$ di setiap sisi), terbuat dari jalinan mata jala hitam 10 $\mathrm{cm}$ berbentuk persegi.

5. Antena sebagai batas samping dari daerah penyeberangan bola, panjang $1,80 \mathrm{~m}$ dan bergaris tengah $10 \mathrm{~mm}$, terbuat dari fiberglass atau bahan sejenis. Antena dipasang pada bagian luar dari setiap pita samping. Tinggi antena di atas net adalah $80 \mathrm{~cm}$. 
6. Bola tersebut memiliki keliling lingkaran 65-67 cm, dengan berat 250-280 gram.

7. Tekanan dalam dari bola tersebut hendaknya sekitar $0.30-0.325 \mathrm{~kg} / \mathrm{cm} 2$ : $0,40-0,45 \mathrm{~kg} / \mathrm{cm} 2$

\section{Metode Drill}

Amung Ma'mum dan Toto Subroto (2001), menyatakan metode drill adalah cara belajar yang lebih menekankan penguasaan komponenkomponen teknik dan mengulangi yang telah dipelajari sebelumnya. Hal yang sama diungkapkan oleh Poerwadarminta (2002), menyatakan bahwa drill merupakan kegiatan melakukan suatu gerakan tertentu secara berulang-ulang tanpa ada gerakan lain yang menyelinginya.

Sugiyanto (2007), memberikan beberapa saran yang perlu dipertimbangkan apabila menggunakan metode drill, yaitu:

a) Drill digunakan sampai gerakan-gerakan yang benar bisa dilakukan secara otomatis atau menjadi terbiasa serta menekankan pada keadaan tertentu gerakan itu harus dilakukan.

b) Pelajar diarahkan agar berkonsentrasi pada kebenaran pelaksanaan gerakan serta ketepatan penggunaanya. Apabila pelajar tetap tidak meningkatkan penguasaan gerakannya, situasinya perlu dianalisis untuk menemukan penyebabnya dan kemudian membuat perbaikan pelaksanaannya.

c) Selama pelaksanaan drill perlu selalu mengoreksi agar perhatian tetap tertuju pada kebenaran gerak.

d) Pelaksanaan drill disesuaikan dengan bagian-bagian dari situasi permainan olahraga yang sebenarnya. Hal ini bisa menimbulkan daya tarik dalam latihan.

e) Perlu dilakukan latihan peralihan dari situasi drill ke situasi permainan yang sebenarnya.

f) Suasana kompetitif perlu diciptakan dalam pelaksanaan drill, tetapi tetap ada kontrol kebenarannya.

Saran-saran dalam metode drill tersebut sangat penting untuk dipahami dan dimengerti oleh seorang guru dalam pelaksanaan keterampilan gerak. Seorang guru harus mampu menyusun tugas-tugas ajar secara baik untuk dapat membelajarkan siswa secara aktif sehingga pelaksanaan proses belajar mengajar dapat terjadi secara kondusif. Hal ini sejalan dengan pendapat Rusli Lutan (1988), menyatakan bahwa keaktifan sendiri dari pihak siswa merupakan kunci utama penguasaan dan pemantapan gerak, kelangsungan proses latihan pada tahap berikutnya ialah penguasaan teknik yang ideal. Hal ini tergantung pada inisiatif dari siswa itu sendiri, sedangkan guru bertugas mengarahkan penguasaan gerak, melakukan koreksi dan evaluasi setiap terjadi kesalahan teknik agar terhindar dari pola gerakan yang salah dari teknik yang dipelajari.

Sugiyanto (2007), menyatakan bahwa dari setiap pelakasanaan drill perlu selalu dikoreksi agar perhatian tertuju pada kebenaran gerak karena dalam pelaksanaan drill ini dilakukan secara berulang-ulang dari pengulangan inilah menjadikan terjadinya otomatisasi gerakan akibat dari kesamaan gerakan yang dilakukan dan tentunya hal ini akan berdampak pada meningkatnya kemampuan teknik dasar yang sedang diajarkan.

Pengertian dari beberapa ahli tersebut dapat disimpulkan bahwa metode drill merupakan pembelajaran yang menekankan pada penguasaan teknik suatu cabang olahraga yang dalam pelaksanaannya dilakukan secara berulang-ulang. Dalam hal ini pembelajaran yang dilaksanakan secara berulang-ulang tidak keluar dari suatu gerakan teknik dasar yang ingin ditingkatkan yaitu teknik passing bawah.

Menurut Hardja Sapoetra

(hardjasapotra.blogspot.co.id), bahwa keunggulan dan kelemahan metode drill sebagai berikut:

1. Keunggulan metode drill

a. Peserta didik memperoleh ketangkasan dan kemahiran dalam melakukan sesuatu sesuai dengan yang dipelajarinya.

b. Menimbulkan rasa percaya diri peserta didik yang berhasil dalam belajar, karena telah memiliki suatu keterampilan khusus yang berguna kelak dikemudian hari. 
c. Guru lebih muda mengontrol dan membedakan mana peserta didik yang disiplin dalam belajarnya dan mana yang kurang disiplin, dengan memperhatikan tindakan dan perbuatan peserta didik saat berlangsungnya pembelajaran.

2. Kelemahan metode drill

a. Menghambat bakat dan inisiatif anak didik karena anak didik lebih banyak dibawa kepada penyesuaian dan diarahkan pada jauh dari pengertian.

b. Membentuk kebiasaan yang kaku artinya seolah-olah peserta didik melakukan sesuatu secara mekanis dalam memberikan stimulus peserta didik bertindak secara otomatis.

c. Menimbulkan penyesuaian secara statis kepada lingkungan, dimana peserta didik menyelesaikan tugas secara statis sesuai dengan apa yang diinginkan oleh guru.

\section{Kerangka Berfikir}

Pelaksanaan kegiatan proses belajar mengajar disekolah metode mengajar merupakan salah satu faktor dari beberapa indikator yang dapat mempengaruhi hasil belajar. Metode pembelajaran pendidikan jasmani yang dikembangkan oleh guru pendidikan jasmani olahraga dan kesehatan selama ini adalah metode pembelajaran yang mudah dan terkesan tradisional dalam menyampaikan materi pelajarannya yaitu dengan metode mengajar yang terpusat pada guru, sedangkan metode mengajar yang terpusat pada siswa, baik individu, kerja sama siswa dalam kelompok, maupun kerja sama antar kelompok dalam memahami isi materi pelajaran dan melaksanakan proses pembelajarannya jarang dilakukan oleh guru.

Pembelajaran pendidikan jasmani terdapat beberapa permainan dan olahraga yang harus dipelajari oleh siswa saat ini diantaranya adalah pembelajaran bola voli khususnya pokok bahasan passing bawah. Banyak metode yang dapat diterapkan untuk dapat meningkatkan hasil belajar passing bawah bola voli diantaranya adalah metode drill.
Metode ini dapat meningkatkan hasil belajar karena gerakannya yang diulang-ulang yang dapat meningkatkan daya ingat siswa dan dalam pelaksanaannya selalu dikoreksi sehingga menambah keingintahuan siswa khususnya dalam permainan bola voli teknik dasar passing bawah.

\section{Hipotesis Tindakan}

Hipotesis penelitian ini adalah penerapan metode drill dapat meningkatkan hasil belajar passing bawah bola voli siswa kelas VII.A SMP Negeri 2 Batukliang.

\section{METODE PENELITIAN}

\section{Jenis Penelitian}

Penelitian ini termasuk penelitian tindakan kelas (classroom action research). Dalam penelitian tindakan kelas ini, ada tindakan (aksi) tertentu untuk meningkatkan hasil belajar passing bawah bola voli siswa kelas VII.A SMP Negeri 2 Batukliang dengan menggunakan metode drill.

\section{Waktu dan Tempat Penelitian}

Penelitian ini dilaksanakan mulai tanggal 2 Agustus sampai dengan tanggal 29 Agustus 2016 semester ganjil tahun pelajaran 2016/2017 SMP Negeri 2 Batukliang pada siswa kelas VII. A sebanyak 23 orang.

Faktor-Faktor yang Diteliti

Faktor-faktor yang diteliti dalam penelitian ini adalah:

\section{Faktor Guru}

Melihat apakah guru telah melaksanakan tahap-tahap pembelajaran pokok bahasan passing bawah bola voli dengan menggunakan metode drill.

2. Faktor Siswa

Melihat apakah siswa telah melaksanakan tahap-tahap proses belajar pokok bahasan passing bawah bola voli dengan menggunakan metode drill.

3. Hasil Belajar Siswa

Melihat hasil belajar siswa dalam pembelajaran pendidikan jasmani olahraga dan kesehatan khususnya pokok bahasan passing bawah permainan bola voli 


\section{Prosedur penelitian}

Penelitian tindakan kelasini dilaksanakan dalam dua siklus yang disesuaikan dengan materi dan alokasi waktu yang diberikan untuk mengajarkan pokok bahasan passing bawah. Prosedur penelitian dilakukan dengan 4 tahap yakni perencanaan, pelaksanaan, observasi atau evaluasi, dan refleksi.

Desain Alur tindakan yang digunakan dalam penelitian tindakan kelas,ini adalah :

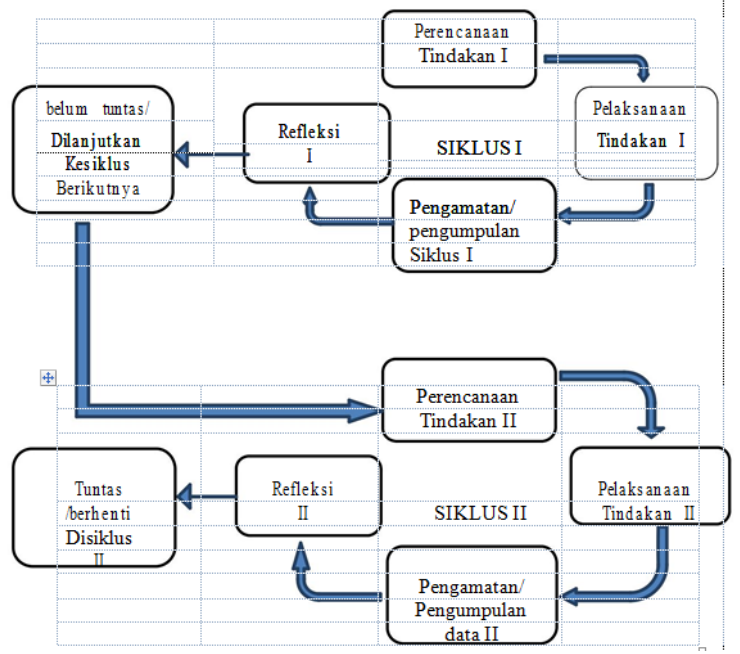

Gambar 3.1 Model Siklus Penelitian Tindakan Kelas

(Suharsimi Arikunto dalam Paizaluddin dan Ermalinda, 2014)

Adapun pelaksanaan tindakan tersebut mengikuti posedur penelitian sebagai berikut:

Siklus I

1. Perencanaan

Kegiatan pada tahap ini meliputi:

a. Berkoordinasi dengan kepala sekolah, guru serta siswa kelas VII.A SMP Negeri 2 Batukliang

b. Menyusun rencana pembelajaran dengan menggunakan metode drill pada pokok bahasan passing bawah dalam permainan bola voli.

c. Membuat alat evaluasi untuk melihat apakah hasil belajar passing bawah dapat meningkat melalui penerapan metode drill

d. Menyiapkan peralatan berupa bola voli, lapangan bola voli dan peluit.

2. Pelaksanaan tindakan
Kegiatan yang dilakukan pada tahap ini adalah peneliti melaksanakan pembelajaran dengan materi pokok passing bawah dalam permainan bola voli. Peneliti melaksanakan pembelajaran dengan cara menyampaikan materi secara lisan kemudian dengan peragaan agar siswa benar-benar mamahami materi yang diajarkan melalui metode drill. Penjelasan ini dimaksud untuk memberikan suatu pemahaman tentang gerakan passing bawah yang dilakukan. Setelah memberikan penjelasan kemudian peserta didik diberikan kesempatan untuk melakukan gerakan passing bawah.

3. Observasi dan evaluasi

Tahap iniadalah guru dan peneliti mencatat tahap-tahap dalam kegiatan belajar mengajar baik yang dilakukan guru maupun siswa dari awal sampai akhir dengan menggunakan format lembar pengamatan guru dan siswa, dan mengevaluasi hasil belajar melalui instrumen tes hasil belajar siswa untuk mengetahui sejauh mana penguasaan siswa dalam melakukan passing bawah.

\section{Refleksi}

Hasil yang diperoleh dari tahap evaluasi, dikumpulkan dan dianalisis dengan tujuan untuk mengetahui kelemahan yang ditemukan selama kegiatan belajar mengajar berlangsung. Segala kelemahan yang terdapat pada tahap ini, peneliti melakukan perbaikan pada siklus berikutnya.

\section{Siklus II.}

1. Perencanaan

Kegiatan pada tahap ini meliputi:

a. Menetapkan kelemahan yang ditemukan pada siklus I.

b. Meninjau kembali perangkat pembelajaran berupa rencana pelaksanaan pembelajaran dengan pokok bahasan passing bawah pada pertemuan kedua untuk diterapkan pada siklus II.

2. Pelaksanaan Tindakan

Kegiatan yang dilakukan pada tahap ini adalah peneliti melaksanakan rencana pelaksanaan pembelajaran dengan materi passing bawah sama dengan pelaksanan 
tindakan siklus 1 hanya saja ada penekananpenekanan tertentu khususnya pada bagian bagian yang menyebabkan rendahnya

ketuntasan pada siklus I baik yang berkaitan dengan aktivitas guru dan siswa dalam kegiatan belajar mengajar maupun tentang hasil belajar siswa dengan menggunakan metode drill.

3. Observasi dan evaluasi

Pada tahap ini, guru dan peneliti kembali melakukan tindakan yakmi mengamati kegiatan belajar mengajar pada pertemuan kedua dengan menggunakan format lembar pengamatan dan mengevaluasi hasil belajar melalui instrumen test hasil belajar siswa sebagai suatu data untuk dianalisis, sehingga hasil analisa ini akan digunakan untuk mengetahui sejauh mana penguasaan siswa tentang teknik passing bawah.

4. Refleksi

Hasil yang diperoleh pada tahap evaluasi dikumpulkan dan dianalisis dengan tujuan untuk mengetahui kekurangan yang ditemukan selama proses belajar mengajar.

\section{Data dan Sumber Data}

1. Data

Jenis data yang diperoleh adalah data kuantitatif dan kualitatif, data kuantitatif diambil dari tes hasil belajar siswa sedangkan data kualitatif diambil dari hasil observasi guru dan siswa kelas VII.A SMP Negeri 2 Batukliang.

2. Sumber Data

Sumber data dalam penelitian ini adalah guru dan siswa kelas VII.A SMP Negeri 2 Batukliang.

\section{Teknik Pengumpulan Data}

Teknik pengumpulan data dalam penelitian tindakan kelas ini terdiri dari tes unjuk kerja dan observasi.

1. Tes unjuk kerja digunakan untuk mendapatkan data tentang hasil teknik dasar passing bawah bola voli yang dilakukan oleh siswa dan tes yang digunakan dalam bentuk uraian.

2. Lembar observasi, di pergunakan sebagai teknik mengumpulkan data tentang aktifitas guru dan siswa selama kegiatan belajar mengajar bola voli yang berfungsi untuk mengetahui adanya keserasian antara perencanaan tindakan, pelaksanaan tindakan dan untuk mengetahui sejauh mana dapat menghasilkan perubahan yang diinginkan oleh peneliti.

Adapun lembar observasi dan teknik untuk mendapatkan data kuantitatif dan kualitatif tentang passing bawah bola voli adalah sebagai berikut:

\section{Tabel 3.1 : Lembaran Observasi Guru}

\begin{tabular}{|c|c|c|c|}
\hline \multirow{2}{*}{ NO } & \multirow{2}{*}{$\begin{array}{c}\text { Aktifitas Guru Selama Proses } \\
\text { Pembelajaran }\end{array}$} & \multicolumn{2}{|c|}{ Hasil pengamatan } \\
\hline & & $\mathrm{Ya}$ & Tidak \\
\hline 1 & $\begin{array}{l}\text { Apakah guru memberikan } \\
\text { pemanasan? }\end{array}$ & & \\
\hline 2 & $\begin{array}{l}\text { Apakah guru menyampaikan } \\
\text { materi pokok }\end{array}$ & & \\
\hline 3 & $\begin{array}{l}\text { Apakah guru menyampaikan } \\
\text { tujuan pembelajaran? }\end{array}$ & & \\
\hline 4 & Apakah guru memotivasi siswa? & & \\
\hline 5 & $\begin{array}{l}\text { Apakah guru menginformasikan } \\
\text { Metode pembelajaran yang } \\
\text { digunakan? }\end{array}$ & & \\
\hline
\end{tabular}

\section{Analisis Data}

Teknik analisis data yang digunakan adalah teknik analisis deskriptif, sebagai berikut:

Tingkat ketuntasan individu, menggunakan rumus:

Nilai Psikomotor

$$
\mathrm{PM} \frac{N P}{N M} 100 \times 50 \%
$$

Nilai Kognitif

$$
\mathrm{K}=\frac{N P}{N M} 100 \times 30 \%
$$

Nilai Afektif

$$
\mathrm{A}=\frac{N P}{N M} 100 \times 20 \%
$$

Nilai Akhir

$$
\mathrm{NA}=\mathrm{PM}+\mathrm{K}+\mathrm{A} \text { Keterangan : }
$$

$\mathrm{NA}=$ Nilai Akhir NM = Nilai Maksimal

\section{Menentukan keberhasilan belajar, menggunakan rumus:}

$$
\mathrm{KB}=\frac{I S T}{J S K} X 100
$$

Keterangan:

$\mathrm{KB}=$ Ketuntasan Belajar

JST = Jumlah Siswa Tuntas

JSK = Jumlah Siswa Keseluruhan 
Sumber, (Depdiknas, 2001)

\section{Indikator}

Indikator keberhasilan dalam penelitian tindakan kelas ini adalah apabila ketuntasan aktivitas guru dan siswa mencapai $85 \%$ dari seluruh indikator dan hasil belajar siswa yang memperoleh nilai 70 sudah mencapai $75 \%$ dari jumlah siswa, maka penelitian ini dikatakan tuntas berdasarkan Kriterai Ketuntasan Minimal ( KKM ) dari sekolah.

\section{HASIL DAN PEMBAHASAN}

Hasil Penelitian

Deskripsi Aktivitas Siswa Selama Kegiatan Belajar Mengajar (KBM) Berlangsung Data aktivitas siswa selama kegiatan belajar mengajar berlangsung dapat dilihat pada tabel 4.1 dan 4.2. Untuk mengetahui aktivitas siswa kelas VII.A SMP Negeri 2 Batukliang pada siklus I dengan pembelajaran menggunakan metode drill dapat dilihat pada tabel berikut ini:

\begin{tabular}{|c|l|c|c|}
\hline \multirow{2}{*}{ No } & \multirow{2}{*}{ Aktifitas Siswa Selama Proses Pembelajaran } & \multirow{2}{*}{ Hasil pengam atan siklus I } \\
\cline { 3 - 4 } & & Ya & Tidak \\
\hline 1 & Apakah siswa melakukan pemanasan? & $V$ & \\
\hline 2 & $\begin{array}{l}\text { Apakah siswa mendengarkan atau memperhatikan } \\
\text { ketika guru memberi pengarahan? }\end{array}$ & $\sqrt{ }$ & \\
\hline 3 & Apakah siswa aktif dalam pembelajaran? & $V$ & \\
\hline 4 & $\begin{array}{l}\text { Apakah siswa mengungkapkan pendapat mengenai } \\
\text { Passing bawah? }\end{array}$ & & $\checkmark$ \\
\hline 5 & $\begin{array}{l}\text { Apakah siswa melakukan teknik passing bawah } \\
\text { secara berulang-ulang? }\end{array}$ & $\sqrt{ }$ & \\
\hline 6 & $\begin{array}{l}\text { Apakah siswa bekerja sama dalam melakukan } \\
\text { pembelajaran? }\end{array}$ & $\sqrt{ }$ & \\
\hline 7 & $\begin{array}{l}\text { Apakah siswa memperhatikan temannya dalam } \\
\text { melakukan teknik passing bawah? }\end{array}$ & $\sqrt{ }$ & \\
\hline 8 & $\begin{array}{l}\text { Apakah siswa mampu mendemonstrasikan teknik } \\
\text { passing bawah? }\end{array}$ & $\sqrt{ }$ & \\
\hline 9 & Apakah siswa bertanya apabila menemui kesulitan? & & $\sqrt{ }$ \\
\hline 10 & Apakah siswa antusias terhadap materi pembelajaran? & & $\sqrt{ }$ \\
\hline & \multicolumn{1}{|c|}{ Jumlah } & 7 & 3 \\
\hline
\end{tabular}

Sementara untuk mengetahui aktivitas siswa kelas VII.A SMP Negeri 2 Batukliang pada setiap siklus II dengan pembelajaran menggunakan metode drill dapat dilihat pada tabel berikut ini:

\section{Deskripsi Hasil Belajar}

Data penelitian untuk hasil belajar siswa kelas VII.A SMP Negeri 2

Batukliang setiap siklus dapat dilihat pada tabel berikut:

Tabel 4.7 : Persentase Ketuntasan Hasil Belajar Siswa siklus I dan Siklus II

\begin{tabular}{|c|c|c|c|c|}
\hline \multirow{2}{*}{ Hasil Belajar } & \multicolumn{2}{|c|}{ Siklus I } & \multicolumn{2}{c|}{ Siklus II } \\
\cline { 2 - 5 } & $\sum$ & $\%$ & $\sum$ & $\%$ \\
\hline Iuntas & 15 & $65,22 \%$ & 21 & $91,30 \%$ \\
\hline Tidak Tuntas & 8 & $34,78 \%$ & 2 & $8,00 \%$ \\
\hline $\begin{array}{l}\text { Peningkatan persentase hasil behjar tian } \\
\text { siklus }\end{array}$ & \multicolumn{2}{|c|}{$65,22 \%$} & $91,30 \%$ \\
\hline
\end{tabular}

Jurnal IImiah Mandala Education
Berdasarkan analisis data hasil penilaian formatif menunjukan bahwa pada siklus I siswa yang tuntas hasil belajarnya sebanyak 15 orang atau $65,22 \%$ dan yang belajarnya belum tuntas sebanyak 8 orang atau $34,78 \%$. Sedangkan pada siklus II siswa yang tuntas hasil belajarnya sebanyak 21 orang atau 91,30\% dan yang tidak tuntas sebanyak 2 orang atau 8,70\%. Jadi ketuntasan belajar siswa kelas VII.A pada siklus II telah mencapai tingkat ketuntasan belajar yang ditetapkan oleh pihak sekolah yaitu minimal $75 \%$ siswa memperoleh nilai 70 .

\section{Kesimpulan}

Berdasarkan hasil analisis data dan pembahasan yang telah dikemukakan sebelumnya, maka hasil penelitian ini dapat disimpulkan sebagai berikut:

1. Aktifitas dan hasil belajar siswa kelas VII.A SMP Negeri 2 Batukliang dengan menggunakan metode drill menunjukan hasil yang maksimal, dimana Pada pada siklus I tingkat ketuntasan aktifitas guru dalam melaksanakan kegiatan pembelajaran baru mencapai $72,72 \%$ dan meningkat pada siklus II menjadi $100 \%$, untuk data ketuntasan belajar siswa $70 \%$ dan mengalami peningkatan pada siklus II menjadi $90 \%$, hal ini telah melebihi standar yang didasarkan kriteria ketuntasan minimal yakni $85 \%$. Sedangkan hasil belajar siswa pada siklus I baru mencapai $65,22 \%$ meningkat pada siklus II menjadi $91,30 \%$ atau telah mencapai tingkat ketuntasan belajar yang ditetapkan oleh sekolah yakni $75 \%$.

2. Penerapan metode drill dapat meningkatkan hasil belajar passing bawah bola voli pada siswa kelas VII.A SMP Negeri 2 Batukliang. Hal ini ditunjang oleh fakta bahwa baik tingkat ketuntasan aktivitas guru dan siswa dalam melaksanakan kegiatan belajar mengajar maupun hasil belajar siswa, telah melampauhi batas ketuntasan belajar yang ditetapkan oleh pihak sekolah.

\section{Saran}


Meningkatkan mutu pendidikan, khususnya dalam penelitian ini yang menerapkan metode drill, maka peneliti menyarankan beberapa hal sebagai berikut yaitu:

1. Bagi sekolah menengah pertama khususnya SMP Negeri 2 Batukliang agar dapat menggunakan metode drill dalam proses pembelajaran pendidikan jasmani khusunya materi bola voli pokok bahasan passing bawah sehingga siswa termotivasi dalam mengikuti proses belajar dan juga akan berdampak pada meningkatnya hasil belajar siswa, dalam hal ini permainan bola voli pokok bahasan passing bawah.

2. Bagi guru pendidikan jasmani olahraga dan kesehatan untuk selalu meningkatkan kreatifitas dan kemampuan mengorganisasi kegiatan pembelajaran sesuai dengan apa yang telah direncanakan, sehingga kegiatan proses belajar dan mengajar bisa berjalan sesuai yang diharapkan.

\section{DAFTAR PUSTAKA}

Ahmadi, Nuril. 2007. Panduan Olahraga Bola Voli. Solo: Era Pustaka Utama

Yunus, M. 1992.Olahraga Pilihan Bola Voli. Jakarta: Depdikbud Dirjen Dikti

Www.pojokilmu.com/gambar-ukuranlapangan-bola-voli.html diakses pada harirabu tanggal 3 Februari 2016 